https://helda.helsinki.fi

\title{
Observations on groundwater-surface water interactions at River Vantaa, Finland
}

\section{Korkka-Niemi, Kirsti}

2012

Korkka-Niemi , K , Kivimäki , A-L , Lahti , K, Nygård , M , Rautio , A B K, Salonen , V-P \& Pellikka, P 2012 , ' Observations on groundwater-surface water interactions at River Vantaa, Finland ' , Management of Environmental Quality , vol. 2012/23 , no. 2 , pp. 222-231 . https://doi.org/10.1108/14777831211204958

http://hdl.handle.net/10138/44815

https://doi.org/10.1108/14777831211204958

publishedVersion

Downloaded from Helda, University of Helsinki institutional repository.

This is an electronic reprint of the original article.

This reprint may differ from the original in pagination and typographic detail.

Please cite the original version. 
MEQ

23,2

222

Received 14 April 2011

Revised 25 September 2011

30 September 2011

Accepted 2 November 2011

\section{Observations on groundwater-surface water interactions at River Vantaa, Finland}

\author{
Kirsti Korkka-Niemi \\ Department of Geosciences and Geography, University of Helsinki, Finland \\ Anna-Liisa Kivimäki and Kirsti Lahti \\ The Water Protection Association of the River Vantaa and Helsinki Region, \\ Helsinki, Finland, and \\ Maria Nygård, Anne Rautio, Veli-Pekka Salonen and Petri Pellikka \\ Department of Geosciences and Geography, University of Helsinki, \\ Helsinki, Finland
}

\begin{abstract}
Purpose - The purpose of this paper is to emphasize the importance of groundwater-surface water interaction when studying, modeling and assessing climate change impacts on river water management. Design/methodology/approach - The investigations were focused on River Vantaa and its tributaries in southern Finland. The main methods used involved aerial infrared photography, thermal profiling of river sediments, water quality measurements, isotopic composition of oxygen and hydrogen $\delta^{18} \mathrm{O}, \delta^{2} \mathrm{H}$ and river water temperature measurements. The authors present the first results of the field measurements targeted to identify the groundwater recharge and discharge zones within the river system.

Findings - Groundwater discharge zones were found to have a significant impact on water quality and volume in River Vantaa and its tributaries. In the drainage basin, the aerial infrared photography seemed to be a feasible and cost-effective method to identify areas of groundwater discharge across the entire river basin. Around 350 groundwater/surface water interaction sites along the $220 \mathrm{~km}$ river system could be identified.

Practical implications - The interaction sites identified during the season of low flow rate should be considered as potential risk areas because during flood periods groundwater quality might be at risk due to bank infiltration. This should be considered in river basin management within predicted changing climatic conditions.

Originality/value - This is the first attempt in Finland to map systematically groundwater and river water interactions. The focus of the paper is relevant, because according to the existing climate scenarios, flooding of the main rivers in Finland will be more frequent in future, increasing the probability of groundwater-surface water interaction.
\end{abstract}

Keywords Finland, Rivers, Climate change, Groundwater, Floods,

Surface water-groundwater interaction, Aerial infrared photography, River Vantaa

Paper type Technical paper

\section{Introduction}

Jylhä et al. (2004) have constructed national-scale seasonal and annual climate change scenarios for Finland during the twenty-first century. According to predictions the annual mean temperature is projected to rise by $2-5^{\circ} \mathrm{C}$ and the annual mean precipitation 5-40 percent by the 2050s. Lehner et al. (2006) have predicted the rise in flood frequencies in northeastern Europe, but according to Veijalainen et al. (2010) the
Management of Environmental Quality: An International Journal Vol. 23 No. 2, 2012 pp. $222-231$

(C) Emerald Group Publishing Limited 1477-7835

DOI $10.1108 / 14777831211204958$ 
impacts of climate change will not be uniform within Finland. In some parts of the country, the flooding will decrease, but in central lakes and their outflow rivers as well as in some southern watersheds, predicted increase in precipitation will result in intensified floods (Veijalainen et al., 2010). According to Veijalainen et al. (2009) heavy rains during summertime are expected to increase floods in the tributaries of River Vantaa. Summer flood in 2004 caused severe damage at the drainage basin of the River Vantaa and resulted in water quality problems at two major groundwater intake plants in Riihimäki and Hyvinkää (Suhonen and Rantakokko, 2006).

Management of water resources in Finland has traditionally focussed on either surface water or groundwater. However, surface water is commonly hydraulically connected to groundwater and vice versa (Fleckenstein et al., 2010). Management of one component of the hydrologic system is only partly effective because each hydrologic component is in continuing interaction with other components; and development or contamination of one affects also the other (Winter et al., 1998). Because the interaction is difficult to observe, it is usually ignored in water management considerations (Krause et al., 2007). Moreover, according to Dahl et al. (2007) the EU Water Framework Directive outlines a new approach to water administration in which interactions between groundwater bodies, groundwater dependent terrestrial ecosystems and surface water bodies take on a central role. In northern regions there will be a challenge to manage our surface and/or groundwater resources in changing climate conditions as well as in changing water utilization situation. In Denmark Dahl et al. (2007) has developed a new multiscale and process oriented typology integrating interactions between groundwater, riparian areas and wetlands as well streams and rivers.

Here we present the first attempt to study systematically groundwater and stream water interactions in Finland. The research was focussed on the River Vantaa and its tributaries (220 km altogether, Figure 1). The main target of the study is to increase the knowledge about aquifer-river interaction in the study area. The research was expected to give new insights on the water management, which could be used in evaluating possible effects of climate change to river water and groundwater quality and quantity.

The scope of this research project is first, to identify the sections and branches of river systems where significant hydraulic connection between groundwater and river water exists, second, to quantify flux of groundwater into the stream and/or riverbank filtration of surface water to the aquifer through the shoreline in the areas where the aquifer is used for water supply, third, to study seasonal variations in water fluxes between surface water and groundwater and fourth, to evaluate the impacts of water exchange on water quality in the discharge/infiltration zones and especially in pumping wells of groundwater intake plants of the drainage basin area.

In this paper we show the results of the first scope and discuss their practical implications for future studies. The aim of the initial field period was to locate the groundwater recharge and discharge zones within the river system and to test suitable research methodology, which could be applied in groundwater-river water interaction studies.

\section{Study site}

Field studies were performed at River Vantaa and its tributaries Herajoki, Palojoki, Keravanjoki and Tuusulanjoki in July 2010 (Figure 1). The total length of the rivers studied is approximately $220 \mathrm{~km}$ (Table I). River Vantaa is one of the raw water reserves for the Finland's capital area (ca. one million people). In addition, within the River Vantaa drainage basin there are 25 significant aquifers used by the local
Groundwatersurface water interactions

223 
MEQ

23,2

\section{4}

Figure 1.

River Vantaa watershed and the aquifers connected to the river basin

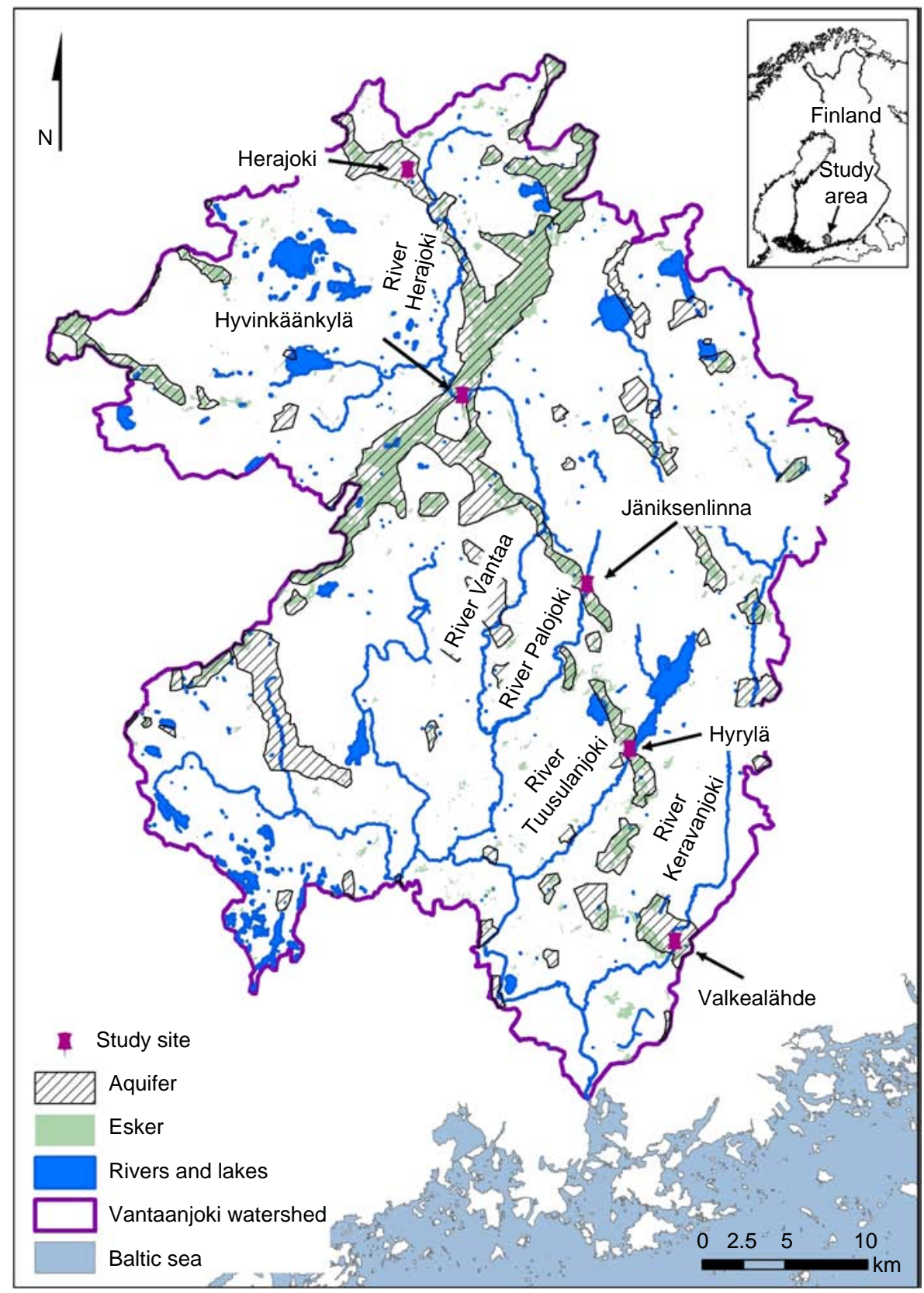

Notes: Field studies performed in 2010 at Rivers Vantaa (Hyvinkäänkylä site), Herajoki, Palojoki (Jäniksenlinna site), Keravanjoki (Valkealähde site) and Tuusulanjoki (Hyrylä site) 
municipalities or water companies (Table I, Figure 1). River Vantaa and its tributaries are also widely used for recreational activities. The quality of the rivers has been monitored regularly since 1970 s in order to identify the incoming load and contaminants.

The River Vantaa drainage basin is rather flat lying or smoothly undulating glacial landscape. Precambrian bedrock is covered by a continuous layer of glacial and postglacial sediments deposited during the Weichselian glacial stage and Holocene. Till makes the lowermost sediment unit (Lunkka et al., 2004; Saarnisto and Salonen, 1995; Tikkanen, 1989, Table II). Aquifers are related to glaciofluvial sand and gravel deposits, i.e. eskers or ice-marginal end moraine complexes. They are normally unconfined, but also semi-confined or confined parts of the aquifers exist, because clays deposited in glaciolacustrine lakes or Baltic Sea often cover the surface of the terrain.

\section{Research methods}

All existing data from the national groundwater database (HERTTA database) and previous site-specific hydrogeological reports of the aquifers as well as river water monitoring results were collected and analyzed. The additional methods used in this study involved aerial infrared photography, thermal profiling of river sediments, water quality measurements (electrical conductivity, $\mathrm{pH}$, main ionic concentration, isotopic composition of oxygen and hydrogen $\left.\delta^{18} \mathrm{O}, \delta^{2} \mathrm{H}\right)$, river water temperature

\begin{tabular}{lccc}
\hline River & Length $(\mathrm{km})$ & Width $(\mathrm{m})$ & Number of aquifers \\
\hline & & & 11 \\
Vantaa & 99 & $20-70$ & 1 \\
Herajoki & 7 & $<5-6$ & 0 \\
Paalijoki & 8 & $<5$ & 0 \\
Kytäjoki & 8 & $5-25$ & 8 \\
Keravanjoki & 65 & $<10-60$ & 2 \\
Tuusulanjoki & 15 & $<10-25$ & 1 \\
Palojoki & 45 & $<5-20$ & 2 \\
Lepsämänjoki & 37 & $<5-15$ & 0 \\
Luhtajoki & 46 & & 25 \\
Total & 330 & &
\end{tabular}

\section{Groundwater- surface water interactions}

225

Aquifers and riverbeds within the River Vantaa drainage basin

\begin{tabular}{|c|c|c|c|c|c|c|}
\hline $\begin{array}{l}\text { River basin } \\
\text { (total area } \mathrm{km}^{2} \text { ) }\end{array}$ & $\begin{array}{c}\text { Bedrock } \\
\text { terrain } \\
(\%)\end{array}$ & $\begin{array}{c}\text { Glacigenic } \\
\text { till }(\%)\end{array}$ & $\begin{array}{l}\text { Glaciofluvial } \\
\text { sand and } \\
\text { gravel }(\%)\end{array}$ & $\begin{array}{c}\text { Marine, } \\
\text { lacustrine } \\
\text { and littoral silt } \\
\text { and clay }(\%)\end{array}$ & $\begin{array}{c}\text { Biogenic } \\
\text { peat } \\
\text { deposit } \\
(\%)\end{array}$ & \\
\hline Vantaa $(1,680)$ & 7.0 & 24.6 & 20.3 & 38.7 & 9.4 & Table II. \\
\hline Keravanjoki (395) & 5.0 & 24.8 & 21.1 & 38.2 & 10.9 & The coverage of \\
\hline Tuusulanjoki (128) & 4.6 & 19.3 & 20.2 & 48.8 & 7.0 & geomorphological units \\
\hline Palojoki (92) & 2.9 & 30.9 & 18.0 & 44.6 & 3.6 & within River Vantaa \\
\hline Luhtajoki (155) & 6.8 & 17.4 & 18.6 & 52.1 & 5.4 & drainage basin \\
\hline Lepsämänjoki (213) & 21.3 & 19.9 & 12.0 & 38.1 & 8.7 & (Tikkanen, 1989) \\
\hline
\end{tabular}


MEQ

23,2

226 measurements and measurements with seepage meters and mini-piezometers (Korkka-Niemi et al., 2011).

Aerial infrared imagery was acquired using Thermo Vision A40 sensor, which has a 320 times 240 focal plane array with the sensitivity for $7.5-13 \mu \mathrm{m}$ of the electromagnetic spectrum. The field of view of the camera is $24 \times 18^{\circ}$. Based on the FLIR systems, the temperature differences as small as $0.08^{\circ} \mathrm{C}$, with an accuracy of $\pm 2^{\circ}$, could be measured. The camera was mounted in a pod of a side of a Raven R44 II helicopter together with Nikon D1X digital camera. All together $\sim 10,000$ images were acquired from 100 to 250 above ground surface following the river courses on July 16 and July 28. The flying height above ground between 100 and 250 meters produced ground resolution between 0.13 and $0.33 \mathrm{~cm}$. Aerial infrared imagery was used to identify areas of discrete and diffuse discharge of groundwater to stream water based on the temperature contrast between surface water and groundwater (Torgersen et al., 2001; Anderson, 2005).

Field measurements with multiparameter probe (YSI 600 XLM-V2-M) and multilevel sediment temperature probe (TP62_S, Umwelt Elektronik GmbH) were done at selected river sections concurrently with the aerial photography. Moreover, automatic YSI 600 sensors were installed at three water supply sites. Exceptionally arid and warm period preceded the time of the field activities resulting in the high difference between the temperature of river water $\left(+20\right.$ to $\left.+24^{\circ} \mathrm{C}\right)$ and groundwater $\left(+4\right.$ to $\left.+8^{\circ} \mathrm{C}\right)$.

\section{Results and discussion}

More than 350 locations with groundwater-surface water interaction along the $220 \mathrm{~km}$ long river system could be depicted. Based on aerial infrared photography and site-specific field measurements, groundwater-surface water interaction sites could be identified and classified into the four main categories (Figure 2):

- Category 1: a spring discharging into the river. This can be observed as cold spots next to the river or in the riverbank.

- Category 2: a ditch/creek discharging into the river. Cold groundwater originates from spring areas further from the riverbank.

- Category 3: diffuse discharge of groundwater along the shoreline.

- Category 4: diffuse discharge over a wide seepage area around a riverbed.

There were 67 visible springs and 64 notable ditches or creeks discharging groundwater into the river (Table III). There were also over 200 areas along the studied river system, where diffuse groundwater discharge either by a shoreline or over a wide area around a riverbed could be observed.

According to Winter et al. (1998) the withdrawal of water from a stream can deplete groundwater or conversely, pumping of groundwater can affect the stream water quality and quantity. Similarly the pollution of either surface water or groundwater body can degrade the other. As Winter et al. (1998) has summarized, effective water management requires a clear understanding of the linkages between groundwater and surface water bodies at any hydrologic settings. This is easy to understand when observing, e.g. River Vantaa cutting an esker formation of 


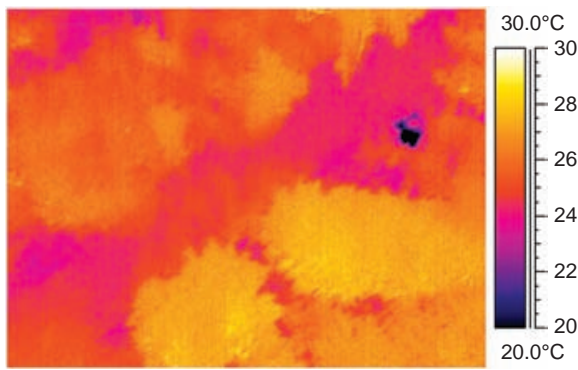

Category 1: a spring discharging groundwater into a river
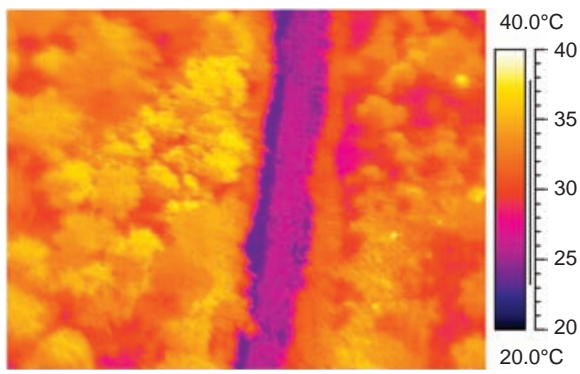

Category 3: diffuse discharge by a shoreline around a riverbed
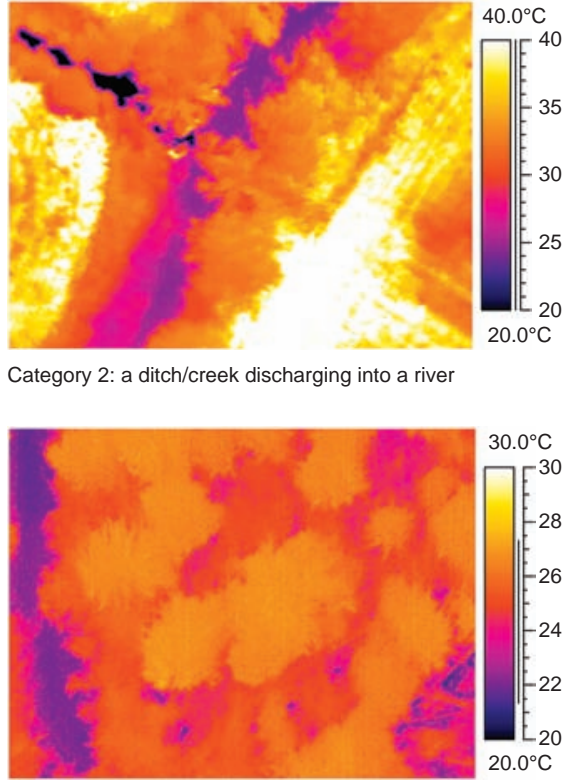

$30.0^{\circ} \mathrm{C}$

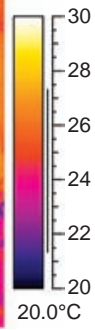

Category 4: diffuse discharge over a wide seepage area
Groundwatersurface water interactions

227

Figure 2.

Categories of discrete and diffuse groundwater discharge areas

\begin{tabular}{lcccc}
\hline River & $\begin{array}{c}\text { Category } 1 \\
\text { spring }\end{array}$ & $\begin{array}{c}\text { Category } 2 \\
\text { ditch/creek }\end{array}$ & $\begin{array}{c}\text { Category } 3 \\
\text { diffuse by shoreline }\end{array}$ & $\begin{array}{c}\text { Category 4 } \\
\text { diffuse wide seepage area }\end{array}$ \\
\hline
\end{tabular}

$\begin{array}{lrr}\text { Vantaa } & 36 & 27 \\ \text { Herajoki } & 0 & 2 \\ \text { Keravanjoki } & 11 & 23 \\ \text { Tuusulanjoki } & 5 & 7 \\ \text { Palojoki } & 15 & 5 \\ \text { Total } & 67 & 64\end{array}$

$\begin{array}{rr}3 & 76 \\ 1 & 14 \\ 17 & 48 \\ 3 & 31 \\ 2 & 26 \\ 26 & 195\end{array}$

Table III.

The identified discrete and diffuse groundwater discharge areas classified into four categories

Hyvinkäänkylä aquifer (Figure 3). At the Hyvinkäänkylä study site, River Vantaa is $9-14 \mathrm{~m}$ wide, maximum depth is $2 \mathrm{~m}$ and the flow rate in mid-July is $0.7-0.8 \mathrm{~m}^{3} / \mathrm{s}$ (peak flow in April 2010 was $39.24 \mathrm{~m}^{3} / \mathrm{s}$ ). An average river water temperature in July is $17.0-19.3^{\circ} \mathrm{C}$, while during observation days in July 2010 river water temperature was $22-24^{\circ} \mathrm{C}$. The temperature of groundwater in Finland is generally between +4 and $+8^{\circ} \mathrm{C}$. Figure 3 displays the groundwater discharge detected as low temperatures in infrared images. There is a groundwater intake plant (in the middle of the Figure 3 ) on the riverbank pumping $3,800 \mathrm{~m}^{3} / \mathrm{d}$ groundwater and it is possible that there is a connection between pumping wells and river water in certain hydrologic conditions.

At four study sites thermal profiling with temperature probe of water and river bottom sediments revealed zones of groundwater discharge and provided reference data for aerial photography data (Figure 4). Seepage meters and mini-piezometers (Baxter et al., 2003; Korkka-Niemi et al., 2009; Rautio and Korkka-Niemi, 2011) were 
MEQ

23,2

\section{8}

Figure 3.

River Vantaa cutting the esker formation of the Hyvinkäänkylä aquifer

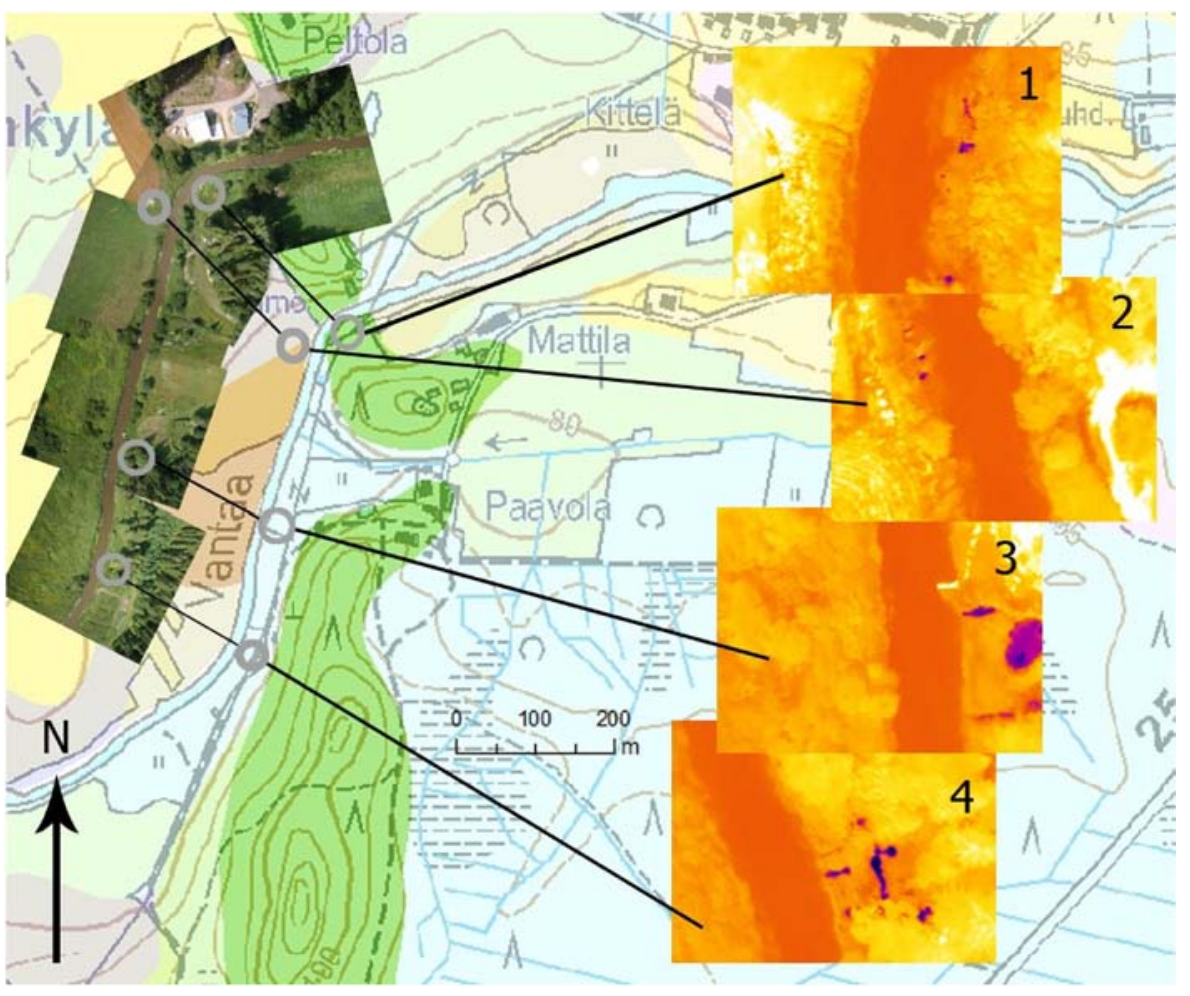

Notes: Dark areas represent the groundwater discharge zones

used at selected locations in order to quantify the observed flux of groundwater into the stream and to take water samples. The aerial infrared photography seemed to be feasible and cost-effective method to identify areas of groundwater discharge across the entire river basin as also, e.g. Conant et al. (2009) has noticed earlier in Canada.

\section{Future research interests}

In next steps of the research we will use water quality data $\left(\mathrm{O}_{2}, \mathrm{pH}, \mathrm{EC}\right.$, turbidity, suspended solids, $\mathrm{COD}_{\mathrm{Mn}}$, total phosphorus, total nitrogen, $\mathrm{NO}_{3}-\mathrm{N}, \mathrm{NO}_{2}-\mathrm{N}, \mathrm{NH}_{4}-\mathrm{N}$, enterococci, $E$. coli bacteria), main ionic concentrations, DOC and isotopic composition of oxygen, hydrogen and dissolved inorganic carbon $\left(\delta^{18} \mathrm{O}, \delta^{2} \mathrm{H}, \delta^{13} \mathrm{C}\right)$ of river water, groundwater and discharging water to determine shares of surface water and groundwater within the identified mixing zones.

Quantification of groundwater flux into the river and vice versa will be observed with seepage meters and mini-piezometers and using more detailed thermal profiling of river water and the sediment. In narrow and shallow tributaries, the stream discharge will be measured directly with a flow meter.

In addition, the future target is to test and create methods to assess and estimate the effects of changing groundwater intake into the aquifer and connected surface water body (Rosenberry and LaBaugh, 2008; Poulsen et al., 2011). This could be done using 3D mathematical and hydrogeochemical modelling (Stauffer et al., 2008). 


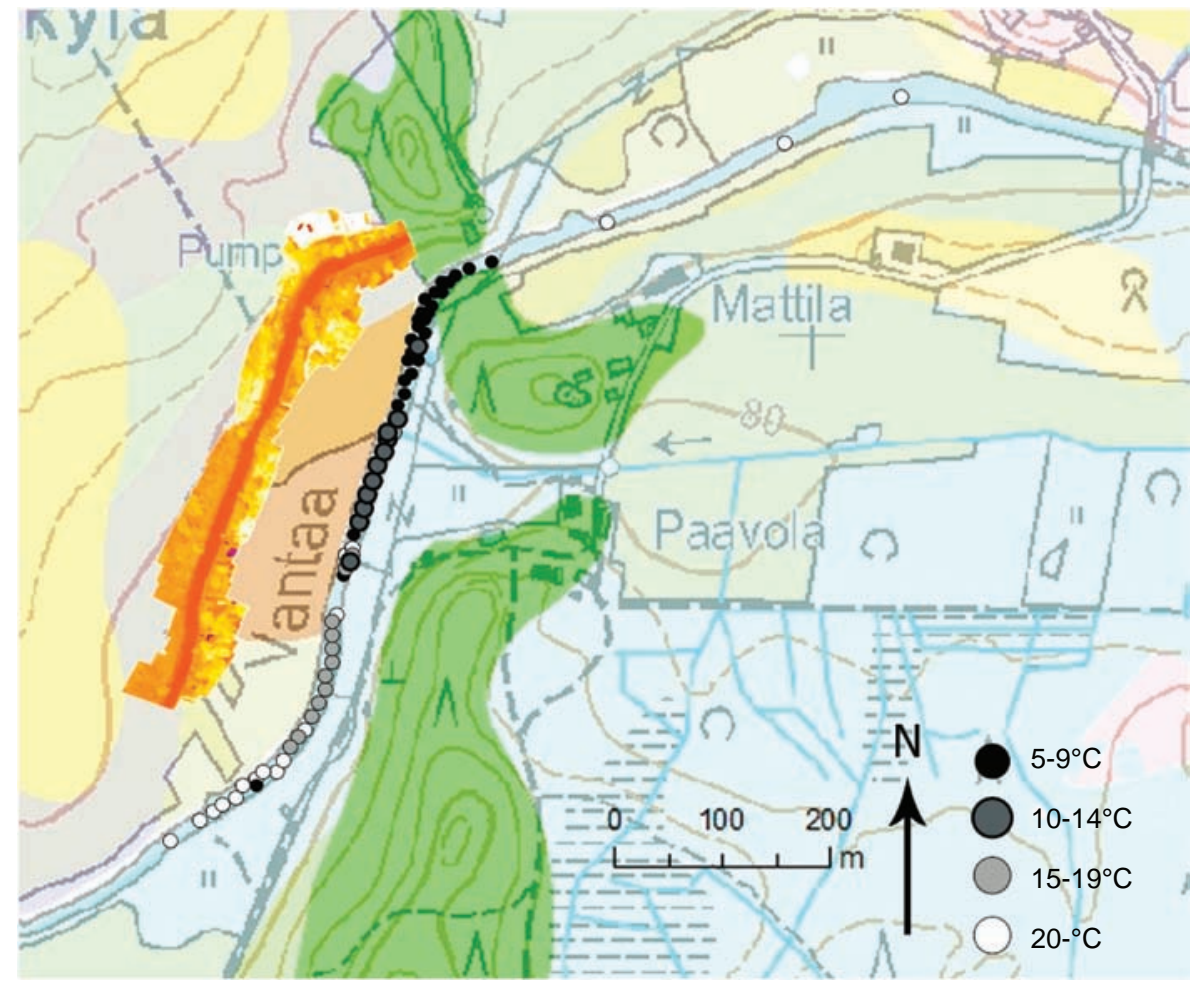

Groundwatersurface water interactions

229

Figure 4. Measured water temperatures above the riverbed sediments in Hyvinkäänkylä study site

\section{Conclusion}

In the River Vantaa drainage basin, there is a need for greater understanding of the interaction of ground water and surface water with respect to the water supply, water quality and characteristics of aquatic environments in changing climatic conditions.

The aerial infrared photography was found to be feasible and cost-effective method to identify areas of groundwater discharge across the river basin. According to aerial infrared photography and site-specific measurements, around 350 groundwater-surface water interaction sites along the 220-km-long river system could be located.

Groundwater discharge zones may have more significant impact on water quality and quantity in the River Vantaa and its tributaries than has thus far been acknowledged. The interacting locations identified during the low-flow season in July 2010 should be considered as potential risk areas during flood periods (groundwater quality deterioration due to bank infiltration) and should be taken under considerations in river water basin management in changing climatic situations.

In future, water quality data, stable isotopic compositions of waters, stream flow measurements, seepage measurements, thermal profiling, additional aerial infrared photographing and mathematical and hydrogeochemical modelling will be used in order to assess the interaction between groundwater aquifers and river. 
MEQ

23,2

230

\section{References}

Anderson, M.P. (2005), "Heat as a ground water tracer", Ground Water, Vol. 43 No. 6, pp. 951-68.

Baxter, C., Hauer, R.F. and Woessner, W.W. (2003), "Measuring groundwater-stream water exchange: new techniques for installing minipiezometers and estimating hydraulic conductivity", Trans. Am. Fisheries Soc., Vol. 132 No. 3, pp. 493-502.

Conant, Jr. B., Mochnacz, N.J. and Utting, N.C. (2009), "Infrared Thermography and Geochemistry to Identify Ground Water Discharge Locations for Fish Habit Assessments. NGWA Groundwater Summit 2009”, Program and abstracts, Tucson, AZ, 19-23 April, available at: http:// ngwa.confex.com/ngwa/2009gws/webprogram/Paper6048.html (accessed March 1, 2011).

Dahl, M., Nilsson, B., Langhoff, J.H. and Refsgaard, J.C. (2007), "Review of classification systems and new multi-scale typology of groundwater-surface water interaction", Journal of Hydrology, Vol. 344 Nos 1-2, pp. 1-16.

Fleckenstein, J.H., Stefan Krause, S., Hannah, D.M. and Boano, F. (2010), “Groundwater-surface water interactions: new methods and models to improve understanding of processes and dynamics", Advances in Water Resources, Vol. 33 No. 11, pp. 1291-5.

Jylhä, K., Tuomenvirta, H. and Ruosteenoja, K. (2004), "Climate change projections for Finland during the 21st century", Boreal Environment Research, Vol. 9 No. 2, pp. 127-52.

Korkka-Niemi, K., Rautio, A. and Wiebe, A. (2009), "Methods for investigating groundwater surface water interaction at Lake Pyhäjärvi, SW Finland", 6th National Geological Colloquium 4.-6.3.2009 [Helsinki]: program and abstracts. Publications of the Department of Geology, Series A 3, University of Helsinki, Helsinki, p. 28.

Korkka-Niemi, K., Rautio, A., Niemistö, P. and Karhu, J. (2011), "Hydrogeochemical and isotopic indications of ground water-surface water interaction at Lake Pyhäjärvi, SW Finland", in Schirmer, M., Hoehn, E. and Vogt, T. (Eds), GQ2010: Groundwater Quality Management in a Rapidly Changing World, IAHS Publications 342, Oxfordshire, pp. 423-6.

Krause, S., Bronstert, A. and Zehe, E. (2007), "Groundwater-surface water interactions in a North German lowland floodplain - implications for the river discharge dynamics and riparian water balance", Journal of Hydrology, Vol. 347 Nos 3-4, pp. 404-17.

Lehner, B., Döll, B., Alcamo, J., Henrichs, T. and Kaspar, F (2006), "Estimating the impact of global change on flood and drought risks in Europe: a continental, integrated analysis", Climatic Change, Vol. 75 No. 3, pp. 273-99.

Lunkka, J.P., Johansson, P., Saarnisto, M. and Sallasmaa, O. (2004), "Glaciation of Finland”, in Ehlers, J. and Gibbard, P.L. (Eds), Quaternary Glaciations-Extent and Chronology, Part I Europe, Elsevier, Amsterdam, pp. 93-100.

Poulsen, S.E., Christensen, S. and Rasmussen, K.R. (2011), "The interaction between the unsaturated zone, aquifer, and stream during a period of ground water withdrawal", Journal of Hydrology, Vol. 396 Nos 1-2, pp. 49-60.

Rautio, A. and Korkka-Niemi, K. (2011), "Characterization of groundwater-lake water interactions at Pyhäjärvi, a lake in SW Finland”, Boreal Env. Res., Vol. 16 No. 5, pp. 363-80.

Rosenberry, D.O. and LaBaugh, J.W. (2008), "Field techniques for estimating water fluxes between surface water and ground water", US Geological Survey Techniques and Methods 4-D2, Reston, VA, p. 128.

Saarnisto, M. and Salonen, V.P. (1995), “Glacial history of Finland”, in Ehlers, J., Kozarski, S. and Gibbard, P.L. (Eds), Glacial Deposits in North-East Europe, Balkema, Rotterdam, pp. 3-10.

Suhonen, V. and Rantakokko, K. (2006), "Vantaanjoen tulvatorjunnan toimintasuunni-telma", Uudenmaan ympäristökeskuksen raportteja 1/2006, Edita Prima Oy, Helsinki (in Finnish).

Stauffer, F., Dopler, T. and Hendricks Franssen, H. (2008), "How successful are standard models of groundwater-river interactions", Paper presented at the IAHS-AISH Publication 320, pp. 163-8. 
Tikkanen, M. (1989), "Geomorphology of the Vantaanjoki drainage basin southern Finland", Fennia, Vol. 167 No. 1, pp. 19-72.

Torgersen, C.E., Faux, R.N., McIntosh, B.A., Poage, N.J. and Norton, D.J. (2001), "Airborne thermal remote sensing for water temperature assessment in rivers and streams", Remote Sens. Environ., Vol. 76 No. 3, pp. 386-98.

Veijalainen, N., Sippel, K. and Vehviläinen, B. (2009), “Tulvien muuttuminen Vantaanjoella ja Espoonjoella”, in Helsingin seudun ympäristöpalvelut - kuntayhtymä, Climate is Changing in The Helsinki Metropolitan Area. Background Studies for the Adaptation Strategy, HSY: n julkaisuja 3/2010, Helsinki, pp. 37-53 (abstract in English).

Veijalainen, N., Lotsari, E., Alho, P., Vehviläinen, B. and Käyhkö, J. (2010), "National scale assessment of climate change impacts on flooding in Finland", Journal of Hydrology, Vol. 391 Nos 3-4, pp. 333-50.

Winter, T.C., Harvey, J.W, Franke, O.L. and Alley, W.M. (1998), “Ground water and surface water a single resource”, US Geological Survey Circular 1139, Denver, CO, p. 87.

\section{About the authors}

Kirsti Korkka-Niemi is a Senior Lecturer and Adjunct Professor in Hydrogeology at the University of Helsinki. Her expertise is in hydrogeology, hydrogeochemistry and environmental geology. Kirsti Korkka-Niemi is the corresponding author and can be contacted at: kirsti. korkka-niemi@helsinki.fi

Anna-Liisa Kivimäki is a Hydrogeologist at the Water Protection Association of the River Vantaa and Helsinki Region. Her expertise is in hydrogeology, geomicrobiology and environmental geology.

Kirsti Lahti is a Managing Director of the Water Protection Association of the River Vantaa and Helsinki Region. Her expertise is in environmental microbiology and limnology.

Maria Nygård (BEng) is a Master's student in Hydrogeology at the University of Helsinki.

Anne Rautio is a PhD student in Hydrogeology at the University of Helsinki.

Veli-Pekka Salonen is a Professor in Quaternary and Environmental Geology at the University of Helsinki.

Petri Pellikka is a Professor in Geography at the University of Helsinki. His expertise is in remote sensing of land cover.

\section{Groundwater- surface water interactions}

231 